\title{
ANALISIS LAJU PERTUMBUHAN DAN STRUKTUR EKONOMI KABUPATEN SRAGEN
}

\author{
Lilis Anisah \\ Fungsional Statistisi BPS Kota Semarang Provinsi Jawa Tengah, \\ Jalan Kalisemarang Nomor 1, Semarang \\ lilis.anisah@bps.go.id
}

\begin{abstract}
This research is aimed to determine the leading and potential industrial categories by analyzing of economic growth rate and structure in Sragen Regency. The data used in this study are taken from the Statistics Agency (BPS) including economic growth rate and structure data at 2010 to 2017 in both Sragen Regency and Central Java. The analysis method used are $L Q$ and Klassen Typology. The result of the $L Q$ analysis show that the leading industrial categories in Sragen Regency cover $A, B, D, E, G$, the join of $M$ and $N, P$ category, then the join of $R, S, U$ and $T$ categories. The result of the Klassen Typology analysis state that Sragen Regency is a potential area to grow and develop economically.
\end{abstract}

Keywords: economic growth rate, economic structure, LQ, Klassen TypologyAbstraksi.

Penelitian ini dilakukan dengan tujuan untuk mengetahui lapangan usaha unggulan dan potensi di Kabupaten Sragen dengan menganalisis laju pertumbuhan dan struktur ekonominya. Data yang digunakan dalam penelitian ini bersumber dari Badan Pusat Statistik (BPS) mencakup data PDRB atas dasar harga berlaku dalam delapan tahun terakhir yaitu tahun 2010 sampai 2017 dan data PDRB atas dasar harga konstan dalam tujuh tahun terakhir yaitu tahun 2011 sampai 2017 di wilayah Kabupaten Sragen maupun Provinsi Jawa Tengah. Metode analisis yang digunakan adalah LQ dan Tipologi Klassen. Analisis LQ memberikan hasil bahwa kategori lapangan usaha unggulan Kabupaten Sragen meliputi kategori $A, B, D, E, G$, gabungan $M$ dan $N$, kategori $P$ serta gabungan $R$, $S, U$ dan T. Analisis Tipologi Klassen menunjukkan bahwa Kabupaten Sragen merupakan wilayah yang memiliki potensi untuk tumbuh dan berkembang secara perekonomian.

Kata kunci: laju pertumbuhan ekonomi, struktur ekonomi, LQ, Tipologi Klassen

\section{PENDAHULUAN}

Kabupaten Sragen merupakan kabupaten dengan posisi paling timur di Provinsi Jawa Tengah. Fakta data menunjukkan bahwa kontribusi perekononomian Kabupaten Sragen terhadap perekonomian Jawa Tengah walau tidak terlalu menonjol namun menunjukkan peningkatan. Kondisi tersebut tersebut dapat diketahui dari sumbangsih perekonomian Kabupaten Sragen terhadap perekonomian Jawa
Tengah dalam delapan tahun terakhir. Pada 2010 sumbangsih perekonomian Kabupaten Sragen sebesar 2,54 persen dari perekonomian Jawa Tengah, menempati peringkat ke tiga belas. Pada tiga tahun terakhir posisi Kabupaten meningkat menjadi peringkat sebelas dengan kontribusi yang merangkak naik, dari 2, 71 persen pada 2015, menjadi 2,73 dan 2,74 pada 2016 dan 2017 (BPS, 2010-2017). 
Tabel 1. Distribusi Persentase PDRB Seri 2010 Atas Dasar Harga Berlaku Menurut Lapangan Usaha (Persen) Kabupaten Sragen

\begin{tabular}{|c|c|c|c|c|c|c|c|c|c|}
\hline \multirow{2}{*}{$\begin{array}{l}\text { Kate } \\
\text { gori }\end{array}$} & \multirow{2}{*}{ Lapangan Usaha. } & \multicolumn{8}{|c|}{ Tahun } \\
\hline & & 2010 & 2011 & 2012 & 2013 & 2014 & 2015 & $2016 *$ & $2017 * * *$ \\
\hline (1) & (2) & (3) & (4) & (5) & (6) & (7) & (8) & (9) & $(10)$ \\
\hline $\mathbf{A}$ & $\begin{array}{l}\text { Pertanian, Kehutanan, dan } \\
\text { Perikanan }\end{array}$ & 20.27 & 19.87 & 20.06 & 20.20 & 17.68 & 17.37 & 16.52 & 15.74 \\
\hline B & $\begin{array}{l}\text { Pertambangan dan } \\
\text { Penggalian }\end{array}$ & 2.56 & 2.48 & 2.43 & 2.42 & 2.71 & 2.90 & 2.92 & 2.94 \\
\hline $\mathbf{C}$ & Industri Pengolahan & 28.40 & 30.20 & 30.92 & 31.20 & 33.47 & 34.40 & 35.38 & 36.07 \\
\hline D & Pengadaan Listrik dan Gas & 0.16 & 0.16 & 0.15 & 0.15 & 0.14 & 0.14 & 0.14 & 0.15 \\
\hline $\mathbf{E}$ & $\begin{array}{l}\text { Pengadaan Air, } \\
\text { Pengelolaan Sampah, } \\
\text { Limbah dan Daur Ulang }\end{array}$ & 0.10 & 0.08 & 0.07 & 0.07 & 0.06 & 0.06 & 0.06 & 0.06 \\
\hline $\mathbf{F}$ & Konstruksi & 7.19 & 6.64 & 6.72 & 6.74 & 6.81 & 6.76 & 6.71 & 6.68 \\
\hline $\mathbf{G}$ & $\begin{array}{l}\text { Perdagangan Besar dan } \\
\text { Eceran; Reparasi Mobil dan } \\
\text { Sepeda Motor }\end{array}$ & 22.11 & 21.91 & 20.54 & 20.14 & 19.62 & 19.07 & 18.81 & 18.61 \\
\hline $\mathbf{H}$ & $\begin{array}{l}\text { Transportasi dan } \\
\text { Pergudangan }\end{array}$ & 2.60 & 2.41 & 2.40 & 2.41 & 2.54 & 2.50 & 2.39 & 2.44 \\
\hline $\mathbf{I}$ & $\begin{array}{l}\text { Penyediaan Akomodasi dan } \\
\text { Makan Minum }\end{array}$ & 3.09 & 2.93 & 2.85 & 2.74 & 2.82 & 2.85 & 2.94 & 3.01 \\
\hline $\mathbf{J}$ & Informasi dan Komunikasi & 1.24 & 1.19 & 1.16 & 1.11 & 1.12 & 1.09 & 1.12 & 1.20 \\
\hline $\mathbf{K}$ & $\begin{array}{l}\text { Jasa Keuangan dan } \\
\text { Asuransi }\end{array}$ & 2.82 & 2.70 & 2.79 & 2.73 & 2.73 & 2.74 & 2.80 & 2.85 \\
\hline $\mathbf{L}$ & Real Estate & 0.94 & 0.88 & 0.87 & 0.87 & 0.88 & 0.88 & 0.88 & 0.88 \\
\hline $\begin{array}{c}\text { M\& } \\
\mathbf{N}\end{array}$ & Jasa Perusahaan & 0.37 & 0.37 & 0.37 & 0.38 & 0.38 & 0.39 & 0.40 & 0.42 \\
\hline $\mathbf{O}$ & $\begin{array}{l}\text { Administrasi Pemerintahan, } \\
\text { Pertahanan dan Jaminan } \\
\text { Sosial Wajib }\end{array}$ & 2.77 & 2.51 & 2.52 & 2.44 & 2.36 & 2.30 & 2.27 & 2.21 \\
\hline $\mathbf{P}$ & Jasa Pendidikan & 2.94 & 3.36 & 3.88 & 4.09 & 4.29 & 4.23 & 4.32 & 4.42 \\
\hline $\mathbf{Q}$ & $\begin{array}{l}\text { Jasa Kesehatan dan } \\
\text { Kegiatan Sosial }\end{array}$ & 0.68 & 0.69 & 0.74 & 0.74 & 0.75 & 0.75 & 0.75 & 0.75 \\
\hline $\begin{array}{l}\mathbf{R}, \mathbf{S}, \\
\mathbf{T} \& \mathbf{U}\end{array}$ & Jasa lainnya & 1.76 & 1.62 & 1.53 & 1.58 & 1.63 & 1.58 & 1.59 & 1.57 \\
\hline
\end{tabular}

Sumber: $\quad$ 1. https://sragenkab.bps.go.id/subject/52/produk-domestik-regional-bruto--lapangan-usaha.html\#subjekViewTab5

2. PDRB Kab Sragen menurut Lapangan Usaha 2013-2017

Catatan: $\quad *=$ Angka Sementara,$* *=$ Angka Sangat Sementara 
Berbatasan dengan Kabupaten Ngawi, Provinsi Jawa Timur, BPS menyebutkan bahwa sebesar 73,02 persen dari luas wilayah Kabupaten Sragen merupakan lahan pertanian (Kabupaten Sragen dalam Angka, 2018). Tabel 1 menunjukkan bahwa luasnya lahan pertanian yang dimiliki Kabupaten Sragen ternyata tidak serta merta menjadikan kategori lapangan usaha Pertanian, Kehutanan dan Perikanan sebagai penopang terbesar perekonomian Kabupaten Sragen. Kategori lapangan usaha Pertanian, Kehutanan dan Perikanan hanya mampu menempati urutan ke tiga dalam menopang perekonomian Kabupaten Sragen, susul menyusul dengan kategori lapangan usaha Perdagangan Besar dan Eceran; Reparasi Mobil dan Sepeda Motor. Sedangkan Industri Pengolahan merupakan lapangan usaha yang memberikan sumbangsih terbesar terhadap perekonomian Kabupaten Sragen.

Distribusi persentase PDRB atas dasar harga berlaku (adhb) menurut lapangan usaha merupakan indikator turunan dari data PDRB adhb. Data distribusi persentase PDRB menunjukkan struktur perekonomian atau peranan setiap kategori lapangan usaha dalam perekonomian suatu wilayah. Kategori lapangan usaha yang besar nilai kontribusi atau perannya menunjukkan kategori tersebut menjadi basis atau penopang perekonomian di suatu wilayah.

Dalam kurun waktu 8 tahun, dari tiga penopang utama perokonomian Kabupaten Sragen, kategori lapangan usaha Industri Pengolahan merupakan kategori yang semakin meningkat peranannya. Kategori $\mathrm{G}$ dan A, semakin menurun dari tahun ke tahun. Dapat dicermati pada Tabel 1, bahwa dalam kurun waktu 8 tahun, Industri Pengolahan telah meningkatkan perannya dalam menyusun nilai tambah Kabupaten Sragen, dari 28,40 persen pada 2010 menjadi 36,07 persen pada 2017. Lapangan usaha perdagangan semakin menyusut kontribusinya dari 22,11 persen pada 2010 menjadi 18,61 persen pada 2017. Demikian pula lapangan usaha Pertanian, Kehutanan dan Perikanan menyusut dari 20,27 persen pada 2010 menjadi 15,74 persen pada 2017.

Selain data distribusi persentase PDRB adhb menurut lapangan usaha, indikator makro lain yang dapat menggambarkan kondisi perekonomian suatu wilayah adalah laju pertumbuhan ekonomi. Secara spesifik, laju pertumbuhan ekonomi merupakan salah satu indikator makro yang digunakan untuk mengetahui kinerja perekonomian suatu wilayah (BPS, 2018). Melalui data laju pertumbuhan ekonomi, dapat diketahui perubahan tingkat kegiatan ekonomi suatu wilayah yang berlangsung dari tahun ke tahun (Sukirno, 2010). Laju pertumbuhan ekonomi diturunkan dari data PDRB atas dasar harga konstan (adhk) baik secara keseluruhan maupun setiap kategori dari tahun ke tahun. 
Tabel 2. Laju Pertumbuhan Ekonomi Kabupaten Sragen Tahun 2011-2017

\begin{tabular}{|c|c|c|c|c|c|c|c|}
\hline \multirow{2}{*}{ Kategori Lapangan Usaha } & \multicolumn{7}{|c|}{ Tahun } \\
\hline & 2011 & 2012 & 2013 & 2014 & 2015 & $2016 *$ & $2017 * *$ \\
\hline (1) & (2) & (3) & (4) & (5) & (6) & (7) & (8) \\
\hline $\begin{array}{l}\text { A. Pertanian, Kehutanan dan } \\
\text { Perikanan }\end{array}$ & 4.58 & 3.61 & 4.2 & -7.56 & 3.68 & 1.64 & 0.86 \\
\hline $\begin{array}{l}\text { B. Pertambangan dan } \\
\text { Penggalian }\end{array}$ & 4.38 & 6.8 & 7.06 & 6.99 & 4.33 & 5.17 & 3.87 \\
\hline C. Industri Pengolahan & 7.93 & 10.44 & 9.85 & 11.57 & 8.19 & 7.79 & 8.18 \\
\hline D. Pengadaan Listrik dan Gas & 8.8 & 9.85 & 10.85 & 3.7 & 5.19 & 4.64 & 4.75 \\
\hline $\begin{array}{l}\text { E. Pengadaan Air, } \\
\text { Pengelolaan Sampah, Limbah } \\
\text { dan Daur Ulang }\end{array}$ & -1.2 & -2.58 & -0.15 & 4.44 & 2.42 & 2.66 & 4.6 \\
\hline F. Konstruksi & 1.25 & 6.83 & 6.56 & 5.12 & 5.94 & 6.3 & 5.81 \\
\hline $\begin{array}{l}\text { G. Perdagangan Besar dan } \\
\text { Eceran; Reparasi Mobil dan } \\
\text { Sepeda Motor }\end{array}$ & 8.61 & 1.52 & 5.08 & 5.74 & 4.54 & 4.71 & 4.91 \\
\hline $\begin{array}{l}\text { H. Transportasi dan } \\
\text { Pergudangan }\end{array}$ & 5.97 & 8.51 & 9.55 & 10.44 & 4.94 & 3.38 & 5.11 \\
\hline $\begin{array}{l}\text { I. Penyediaan Akomodasi dan } \\
\text { Makan Minum }\end{array}$ & 4.78 & 5.89 & 2.36 & 8.25 & 6.76 & 8.39 & 8.66 \\
\hline J. Informasi dan Komunikasi & 9.01 & 10.34 & 8.12 & 18.12 & 10.56 & 11.27 & 12.71 \\
\hline $\begin{array}{l}\text { K. Jasa Keuangan dan } \\
\text { Asuransi }\end{array}$ & 3.6 & 3.72 & 3.72 & 7.02 & 6.77 & 7.92 & 6.94 \\
\hline L. Real Estate & 5.87 & 6.69 & 9.09 & 7.83 & 7.19 & 6.74 & 6.85 \\
\hline M, N. Jasa Perusahaan & 8.82 & 6.7 & 8.98 & 8.98 & 8.51 & 8.52 & 9.5 \\
\hline $\begin{array}{l}\text { O. Administrasi } \\
\text { Pemerintahan, Pertahanan } \\
\text { dan Jaminan Sosial Wajib }\end{array}$ & 1.6 & 0.1 & 2.43 & 0.84 & 4.21 & 2.03 & 2.84 \\
\hline P. Jasa Pendidikan & 17.59 & 17.62 & 7.63 & 11.18 & 7.58 & 7.65 & 7.04 \\
\hline $\begin{array}{l}\text { Q. Jasa Kesehatan dan } \\
\text { Kegiatan Sosial }\end{array}$ & 7.92 & 7.9 & 6.29 & 10.16 & 6.08 & 7.08 & 6.86 \\
\hline R,S, T dan U Jasa Lainnya & 2 & 3.13 & 10.01 & 8.57 & 4.08 & 4.76 & 5.35 \\
\hline $\begin{array}{lcr}\text { Sumber: } & 1 . & \begin{array}{r}\text { https://sragenkab.b } \\
\text {.html\#subjekViewTa }\end{array} \\
& 2 . & \text { PDRB Kab Sragen m } \\
\text { Catatan: } & *=\text { Angka Sementara, } * *=A\end{array}$ & ut $\mathrm{La}$ & $\begin{array}{l}\text { ect/52/ } \\
\operatorname{gan} U \\
\text { Seme }\end{array}$ & oduk-do & $\begin{array}{l}\text { estik-r } \\
017\end{array}$ & onal-bi & --lapans & 1-usaha- \\
\hline
\end{tabular}

Tabel 2 menunjukkan bahwa lapangan usaha Industri Pengolahan yang menjadi penopang utama perekonomian Kabupaten Sragen ternyata memiliki laju pertumbuhan yang cukup fluktuatif. Sedangkan lapangan usaha Perdagangan dan Pertanian cenderung melambat. Menarik untuk dicermati, terdapat tiga kategori lapangan usaha dengan laju pertumbuhan yang melampaui laju pertumbuhan tiga kategori dominan penopang perekonomian Kabupaten Sragen. Kategori lapangan usaha tersebut adalah Informasi dan Komunikasi; Penyediaan Akomodasi dan Penyediaan Makan Minum serta lapangan usaha Jasa Perusahaan. Kategori lapangan usaha Informasi dan Komunikasi tumbuh 
dengan laju yang melampaui seluruh kategori lainnya, konsisten sebesar 2 digit dalam tujuh tahun terakhir. Laju pertumbuhan kategori lapangan usaha Jasa Perusahaan menempati posisi ke dua tertinggi setelah kategori Informasi dan Komunikasi dalam tiga tahun terakhir. Sedangkan lapangan usaha Penyediaan Akomodasi dan Penyediaan Makan Minum tumbuh dengan laju tertinggi ke tiga dalam dua tahun terakhir.

Mencermati kondisi tersebut, ingin diketahui kategori lapangan usaha yang memiliki keunggulan dan potensi untuk dapat berkembang berdasarkan alat analisis LQ dan Klassen. Hasil analisis diharapkan bermanfaat bagi pengambil keputusan dalam menentukan kebijakan strategis di bidang perekonomian.

\section{METODE PENELITIAN}

Kabupaten Sragen ditetapkan sebagai obyek penelitian dengan mencermati kondisi laju pertumbuhan, kontribusi ekonomi dan luas lahan yang memiliki potensi untuk maju dan berkembang. Data dalam penelitian ini bersumber dari data time series BPS mencakup data PDRB adhb dalam delapan tahun terakhir, yaitu tahun 2010 sampai 2017 dan data PDRB adhk dalam tujuh tahun terakhir, yaitu tahun 2011 sampai 2017 baik di wilayah Kabupaten Sragen sebagai wilayah analisis maupun Provinsi Jawa Tengah sebagai wilayah referensi.

Penelitian menggunakan LQ dan Klassen sebagai alat untuk menganalisis laju pertumbuhan dan struktur ekonomi Kabupaten Sragen untuk mengetahui kategori lapangan usaha unggulan dan potensi di Kabupaten Sragen.

Analisis LQ merupakan suatu alat analisis data yang dapat digunakan untuk mengkaji kondisi perekonomian suatu wilayah. Dengan analisis LQ, dapat diidentifikasi spesialisasi kategori lapangan usaha yang menjadi basis atau unggulan yang dimiliki oleh suatu wilayah analisis (Adisasmita dalam Nurhasanah dkk, 2018). Analisis LQ dapat pula digunakan untuk mengukur kinerja basis ekonomi suatu wilayah atau pengujian terhadap kategori lapangan usaha yang termasuk dalam kategori unggulan (Ayu dan Wiagustini, 2016).

Analisis Tipologi Klassen merupakan teknik klasifikasi dengan memperhatikan pertumbuhan dan kontribusi kategori lapangan usaha terhadap total PDRB suatu wilayah (Mahmudi, 2009: 52). Analisis Tipologi Klassen bermanfaat untuk mengetahui pola dan struktur ekonomi suatu wilayah dengan membaginya ke dalam empat klasifikasi yaitu kategori maju dan tumbuh pesat, kategori maju namun tertekan, kategori potensial dan masih dapat berkembang dan kategori relatif tertinggal (Nuraini dan Setiartiti, 2017).

\section{HASIL DAN PEMBAHASAN}

1. Hasil Analisis LQ

Analisis LQ membandingkan besarnya peranan atau kontribusi tiap kategori lapangan usaha di wilayah analisis terhadap besarnya peranan kategori tersebut pada wilayah referensi. Dalam penelitian ini, Kabupaten Sragen merupakan wilayah analisis dengan Provinsi Jawa Tengah sebagai wilayah referensi. Untuk mengetahui kontribusi atau peranan di suatu wilayah maka variabel yang digunakan dalam penelitian ini adalah data PDRB adhb. 
Tabel 3. Hasil Analisis Rata-Rata LQ Data PDRB adhb Tahun 2010-2017 menurut Kategori Lapangan Usaha

\begin{tabular}{|c|c|c|c|c|}
\hline No & Kategori Lapangan Usaha & Hasil LQ & Notasi & Sektor \\
\hline$(1)$ & (2) & (3) & (4) & $(5)$ \\
\hline A & Pertanian, Kehutanan, dan Perikanan & 1,19 & + & Unggulan \\
\hline $\mathrm{B}$ & Pertambangan dan Penggalian & 1,22 & + & Unggulan \\
\hline $\mathrm{C}$ & Industri Pengolahan & 0,93 & - & $\begin{array}{l}\text { Bukan } \\
\text { Unggulan }\end{array}$ \\
\hline $\mathrm{D}$ & Pengadaan Listrik dan Gas & 1,56 & + & Unggulan \\
\hline $\mathrm{E}$ & $\begin{array}{l}\text { Pengadaan Air, Pengelolaan Sampah, Limbah } \\
\text { dan Daur Ulang }\end{array}$ & 1,00 & + & Unggulan \\
\hline $\mathrm{F}$ & Konstruksi & 0,67 & - & $\begin{array}{l}\text { Bukan } \\
\text { Unggulan }\end{array}$ \\
\hline G & $\begin{array}{l}\text { Perdagangan Besar dan Eceran; Reparasi } \\
\text { Mobil dan Sepeda Motor }\end{array}$ & 1,44 & + & Unggulan \\
\hline $\mathrm{H}$ & Transportasi dan Pergudangan & 0,83 & - & $\begin{array}{l}\text { Bukan } \\
\text { Unggulan }\end{array}$ \\
\hline I & Penyediaan Akomodasi dan Makan Minum & 0,96 & - & $\begin{array}{l}\text { Bukan } \\
\text { Unggulan }\end{array}$ \\
\hline $\mathrm{J}$ & Informasi dan Komunikasi & 0,36 & - & $\begin{array}{l}\text { Bukan } \\
\text { Unggulan }\end{array}$ \\
\hline $\mathrm{K}$ & Jasa Keuangan dan Asuransi & 0,98 & - & $\begin{array}{l}\text { Bukan } \\
\text { Unggulan }\end{array}$ \\
\hline $\mathrm{L}$ & Real Estate & 0,53 & - & $\begin{array}{l}\text { Bukan } \\
\text { Unggulan }\end{array}$ \\
\hline$M \& N$ & Jasa Perusahaan & 1,18 & + & Unggulan \\
\hline $\mathrm{O}$ & $\begin{array}{l}\text { Administrasi Pemerintahan, Pertahanan dan } \\
\text { Jaminan Sosial Wajib }\end{array}$ & 0,82 & - & $\begin{array}{l}\text { Bukan } \\
\text { Unggulan }\end{array}$ \\
\hline $\mathrm{P}$ & Jasa Pendidikan & 1,04 & + & Unggulan \\
\hline Q & Jasa Kesehatan dan Kegiatan Sosial & 0,94 & - & $\begin{array}{l}\text { Bukan } \\
\text { Unggulan }\end{array}$ \\
\hline $\begin{array}{l}\mathrm{R}, \mathrm{S} \\
\mathrm{T} \& \mathrm{U}\end{array}$ & Jasa lainnya & 1,08 & + & Unggulan \\
\hline
\end{tabular}

Membandingkan besarnya peranan atau kontribusi dapat dimaknai sebagai membandingkan struktur perekonomian. Hasil Analisis LQ pada tabel 3 menyatakan bahwa terdapat delapan kategori lapangan usaha di Kabupaten Sragen yang merupakan kategori unggulan yaitu kategori A, B, D, E, G, gabungan $\mathrm{M} \& \mathrm{~N}, \mathrm{P}$ serta gabungan $\mathrm{R}, \mathrm{S}$, T\&U. Dengan menggunakan data PDRB adhb, dapat diartikan bahwa delapan kategori tersebut dinyatakan unggul di Kabupaten Sragen disebabkan kontribusinya terhadap total perekonomian Kabupaten Sragen lebih besar daripada kontribusi delapan kategori tersebut terhadap total perekonomian Jawa Tengah. Kondisi tersebut ditunjukkan dengan rata-rata LQ PDRB adhb pada delapan tahun terakhir bernilai lebih dari 1 . 
Penelitian sejenis menggunakan analisis LQ dilakukan oleh Nuraini dan Setiartiti (2017) menunjukkan hasil yang hampir mirip, Hasil penelitian menyatakan bahwa kategori D, E, F, G, $\mathrm{H}, \mathrm{I}, \mathrm{J}, \mathrm{K}, \mathrm{L}$, gabungan $\mathrm{M}$ dan $\mathrm{N}, \mathrm{O}, \mathrm{P}, \mathrm{Q}$ dan gabungan $\mathrm{R}, \mathrm{S}, \mathrm{T}$ dan $\mathrm{U}$ merupakan kategori lapangan usaha unggulan di Kota Magelang.

Hasil penelitian Putra dan Yadnya (2018) menyatakan bahwa kategori A, B, F, J, L, O, Q dan gabungan R, S, T dan U merupakan kategori lapangan usaha unggulan di Kabupaten Tabanan, Bali berdasarkan analisis LQ. Nasution dan Suparta (2018) mengimplementasikan analisis LQ dan Shift-Share menemukan bahwa perekonomian Kota Batu mengalami pergeseran struktur dari sektor primer ke sektor sekunder dan juga tersier.

Berdasarkan hasil analisis LQ pada tabel 3, dapat diketahui bahwa dari 17 kategori lapangan usaha, terdapat 8 kategori yang termasuk kategori unggulan seperti dijelaskan sebelumnya. Kedelapan kategori tersebut merupakan sektor basis dan dinilai potensial untuk dapat dikembangkan lebih baik lagi sehingga dapat menggerakkan perekonomian Kabupaten Sragen dengan lebih optimal.

\section{Hasil Analisis Tipologi Klassen}

Penggunaan alat analisis Tipologi Klassen pada penelitian terdahulu dilakukan oleh Putra dan Yadnya (2018). Dengan metode overlay bersama analisis
LQ, diperoleh kesimpulan bahwa sektor unggulan di wilayah Sarbagita adalah sektor perdagangan besar dan eceran, sektor jasa keuangan dan asuransi, sektor jasa pendidikan, sektor penyediaan akomodasi dan makan minum, sektor informasi dan komunikasi, sektor industri pengolahan serta sektor administrasi pemerintah, pertahanan, dan jaminan sosial wajib.

Hasil penelitian Nuraini dan Setiartiti (2017) dengan analisis Klassen menunjukkan bahwa kota Magelang termasuk dalam klasifikasi daerah maju dan berkembang cepat dengan pertumbuhan ekonomi dan pendapatan per kapita yang tinggi. Analisis Klassen pada penelitian Pratiwi dkk (2018) menyatakan bahwa tidak terdapat perubahan dalam jumlah wilayah tertinggal di Provinsi Jawa Timur. Hal ini menunjukkan bahwa pengentasan wilayah tertinggal belum berhasil pada kurun waktu 2011-2015. Pada tahun 2015 wilayah tertekan tumbuh menjadi wilayah maju sehingga komposisi wilayah maju menjadi lebih besar.

Analisis Tipologi Klassen dalam penelitian ini dilakukan dengan membandingkan laju pertumbuhan dan kontribusi dari setiap lapangan usaha di wilayah analisis (Kabupaten Sragen) dengan wilayah referensinya yaitu Provinsi Jawa Tengah. Hasil analisis Tipologi Klassen ditunjukkan pada Tabel 4 dan Tabel 5 berikut. 
Tabel 4. Hasil Analisis Tipologi Klassen Kabupaten Sragen Tahun 2011-2017

\begin{tabular}{|c|c|c|c|c|c|}
\hline Kategori Lapangan Usaha & Gi & $\mathrm{G}$ & $\mathrm{Si}$ & S & $\begin{array}{l}\text { Tipologi } \\
\text { Klassen }\end{array}$ \\
\hline (1) & (2) & (3) & (4) & (5) & (6) \\
\hline $\begin{array}{l}\text { A. Pertanian, Kehutanan dan } \\
\text { Perikanan }\end{array}$ & 1.57 & 2.50 & 18.21 & 15.42 & KW 2 \\
\hline B. Pertambangan dan Penggalian & 5.51 & 6.38 & 2.69 & 2.20 & KW 2 \\
\hline C. Industri Pengolahan & 9.14 & 5.30 & 33.09 & 35.02 & KW 3 \\
\hline D. Pengadaan Listrik dan Gas & 6.83 & 6.33 & 0.15 & 0.09 & KW 1 \\
\hline $\begin{array}{l}\text { E. Pengadaan Air, Pengelolaan } \\
\text { Sampah, Limbah dan Daur Ulang }\end{array}$ & 1.46 & 2.12 & 0.07 & 0.07 & KW 4 \\
\hline F. Konstruksi & 5.40 & 5.36 & 6.72 & 10.17 & KW 3 \\
\hline $\begin{array}{l}\text { G. Perdagangan Besar dan } \\
\text { Eceran; Reparasi Mobil dan } \\
\text { Sepeda Motor }\end{array}$ & 5.02 & 5.05 & 19.81 & 13.85 & KW 2 \\
\hline H. Transportasi dan Pergudangan & 6.84 & 6.98 & 2.44 & 2.98 & KW 4 \\
\hline $\begin{array}{l}\text { I. Penyediaan Akomodasi dan } \\
\text { Makan Minum }\end{array}$ & 6.44 & 6.07 & 2.88 & 3.02 & KW 3 \\
\hline J. Informasi dan Komunikasi & 11.45 & 9.98 & 1.14 & 3.16 & KW 3 \\
\hline K. Jasa Keuangan dan Asuransi & 5.67 & 5.32 & 2.76 & 2.84 & KW 3 \\
\hline L. Real Estate & 7.18 & 6.75 & 0.88 & 1.65 & KW 3 \\
\hline M, N. Jasa Perusahaan & 8.57 & 9.19 & 0.39 & 0.33 & KW 2 \\
\hline $\begin{array}{l}\text { O. Administrasi Pemerintahan, } \\
\text { Pertahanan dan Jaminan Sosial } \\
\text { Wajib }\end{array}$ & 2.01 & 2.39 & 2.37 & 2.91 & KW 4 \\
\hline P. Jasa Pendidikan & 10.90 & 10.96 & 4.08 & 3.99 & KW 2 \\
\hline $\begin{array}{l}\text { Q. Jasa Kesehatan dan Kegiatan } \\
\text { Sosial }\end{array}$ & 7.47 & 9.09 & 0.74 & 0.80 & KW 4 \\
\hline R,S, T dan U Jasa Lainnya & 5.41 & 5.99 & 1.59 & 1.47 & KW 2 \\
\hline
\end{tabular}

Sumber: Data Diolah Peneliti

Keterangan: $\mathrm{Gi}=$ Rata-rata laju pertumbuhan kategori i di Wilayah Analisis

$\mathrm{G}=$ Rata-rata laju pertumbuhan kategori i di Wilayah Referensi

$\mathrm{Si}=$ Rata-rata kontribusi kategori i terhadap PDRB Wilayah Analisis

$\mathrm{S}=$ Rata-rata kontribusi kategori terhadap PDRB Wilayah Referensi

$\mathrm{KW}=$ Kuadran

Tabel 4 menyatakan bahwa dalam kurun waktu 2011-2017, tujuh belas kategori lapangan usaha PDRB terbagi dalam empat kuadran Tipologi Klassen. Klasifikasi kuadran dalam Tipologi
Klassen berdasarkan rata-rata laju pertumbuhan dan kontribusi kategori lapangan usaha terhadap total PDRB digambarkan dalam tabel 5 berikut 
Tabel 5. Klasifikasi Kategori Lapangan Usaha menurut Rata-Rata Laju Pertumbuhan dan Kontribusinya Tahun 2011-2017: Tipologi Klassen

\begin{tabular}{|l|l|}
\hline Kuadran 1 & $\begin{array}{l}\text { Kuadran 2 } \\
\text { Kategori maju namun pertumbuhan } \\
\text { tertekan: Kategori A, B, G, gabungan } \\
\text { Kategori maju dengan pertumbuhan } \\
\text { yang pesat: Kategori D }\end{array}$ \\
\hline \begin{tabular}{l} 
Kuadran 3 \\
\hline $\begin{array}{l}\text { Kategori potensial dan masih dapat } \\
\text { berkembang: Kategori C, F, I, J , K dan } \\
\text { L }\end{array}$
\end{tabular} & $\begin{array}{l}\text { Kuadran 4 } \\
\text { Kategori relatif tertinggal: Kategori E, } \\
\text { H, O dan Q }\end{array}$ \\
\hline
\end{tabular}

Sumber: Data Diolah Peneliti

Kategori D (Pengadaan Listrik dan Gas) merupakan satu-satunya kategori yang termasuk ke dalam kuadran 1. Kategori maju dan tumbuh pesat merupakan cakupan dari kuadran 1, menunjukkan bahwa rata-rata laju pertumbuhan dan kontribusi di Kabupaten Sragen melampaui Provinsi Jawa Tengah.

Kuadran 2 dinyatakan sebagai kategori maju namun pertumbuhannya tertekan. Kategori lapangan usaha yang termasuk ke dalam kuadran 2 menggambarkan bahwa kontribusi masing-masing kategori berikut, yaitu kategori A (Pertanian, Kehutanan dan Perikanan), B (Pertambangan dan Penggalian), G (Perdagangan Besar dan Eceran; Reparasi Mobil dan Sepeda Motor), gabungan M dan N (Jasa Perusahaan), P (Jasa Pendidikan) dan gabungan $\mathrm{R}, \mathrm{S}, \mathrm{T}$ dan $\mathrm{U}$ (Jasa Lainnya) terhadap total PDRB Kabupaten Sragen melampaui kondisi yang sama pada Provinsi Jawa Tengah. Namun demikian, rata-rata laju pertumbuhan kategori tersebut di Kabupaten Sragen lebih kecil daripada rata-rata laju pertumbuhan kategori yang sama di Provinsi Jawa Tengah.

Menarik untuk dicermati, bahwa kategori $\mathrm{G}$ dan A sebagai penopang terbesar ke 2 dan ke 3 perekonomian Kabupaten Sragen berada pada kuadran 2, sedangkan kategori C (Industri Pengolahan) sebagai penopang terbesar terhadap perekonomian Kabupaten Sragen berada pada kuadran 3 menurut hasil analisis Tipologi Klassen. Kategori C bersama lima kategori lainnya yaitu F (Konstruksi), I (Penyediaan
Akomodasi dan Makan Minum), J (Informasi dan Komunikasi), K (Jasa Keuangan dan Asuransi) dan L (Real Estate) merupakan bagian dari kuadran 3. Dapat dimaknai bahwa kategori tersebut memiliki nilai kontribusi lebih kecil terhadap perekonomian Kabupaten Sragen namun laju pertumbuhannya lebih besar daripada kategori yang sama di Provinsi Jawa Tengah.

Empat kategori selebihnya yaitu kategori E, H, O dan Q termasuk dalam Kuadran 4, yaitu kategori yang relatif tertinggal. Dapat diartikan bahwa kategori yang tercakup dalam kuadran 4 merupakan kategori dengan rata-rata laju pertumbuhan dan nilai kontribusinya terhadap total PDRB Kabupaten Sragen lebih kecil dibandingkan dengan rata-rata laju pertumbuhan dan nilai kontribusi kategori yang sama di Provinsi Jawa Tengah. Kategori lapangan usaha yang termasuk dalam Kuadran 1, 2 dan 3 merupakan kategori unggulan berdasar hasil analisis Tipologi Klassen dikarenakan masih ada potensi untuk maju dan berkembang dengan perhatian dari Pemerintah Kabupaten Sragen.

\section{SIMPULAN}

Berdasarkan struktur ekonomi yang dapat dicermati dari data distribusi persentase PDRB adhb Kabupaten Sragen tahun 2010-2017, dapat diketahui bahwa sektor industri, perdagangan dan pertanian menjadi penopang utama 
perekonomian Kabupaten Sragen. Data laju pertumbuhan dalam kurun waktu 2011-2017 menunjukkan bahwa kategori J, I dan gabungan M\&N merupakan kategori yang memiliki potensi untuk dapat dikembangkan dengan laju pertumbuhan yang melampaui kategori penopang utama perekonomian Kabupaten Sragen.

Hasil penelitian berdasarkan analisis LQ menunjukkan bahwa kategori $\mathrm{A}, \mathrm{B}, \mathrm{D}, \mathrm{E}, \mathrm{G}$, gabungan $\mathrm{M} \& \mathrm{~N}, \mathrm{P}$ dan gabungan $\mathrm{R}, \mathrm{S}, \mathrm{T}$ dan $\mathrm{U}$ merupakan kategori unggulan di Kabupaten Sragen. Hasil analisis Tipologi Klassen menyatakan bahwa kategori D merupakan satu-satunya kategori maju dan tumbuh pesat. Kategori A, B, G, gabungan M\&N, $\mathrm{P}$ dan gabungan $\mathrm{R}, \mathrm{S}, \mathrm{T}$ dan $\mathrm{U}$ termasuk ke dalam kategori maju namun tertekan pertumbuhannya. Kategori C, F, I, J, K dan $\mathrm{L}$ termasuk dalam cakupan kategori potensial dan masih dapat berkembang. Sedangkan kategori E, H, O dan Q termasuk ke dalam kategori relatif tertinggal dikarenakan rata-rata laju pertumbuhan dan kontribusinya terhadap perekonomian Kabupaten Sragen lebih kecil nilainya dibandingkan provinsi jawa Tengah.

Dengan mengetahui lebih detail potensi Kabupaten Sragen berdasar data laju pertumbuhan ekonomi, struktur ekonomi dan hasil analisisnya, diharapkan akan memberi manfaat baik bagi peneliti, calon investor maupun pemerintah daerah dalam penentuan prioritas kebijakan terkait strategi pembangunan perekonomian Kabupaten Sragen.

\section{DAFTAR PUSTAKA}

Adisasmita, R. 2005. Dasar-Dasar Ekonomi Wilayah. Cetakan Pertama. Yogyakarta: Graha Ilmu.

Ayu, Fajar Nur dan Wiagustini. 2016. Potensi Ekonomi Daerah Provinsi Bali. E-Jurnal Manajemen Unud, 5 (12): 7528-7554.

Badan Pusat Statistik Kabupaten Sragen. Januari 2019. https://sragenkab.bps.go.id/subject/52/produk-domestik-regional-bruto--lapanganusaha-.html\#subjekViewTab5. "Distribusi Persentase PDRB Seri 2010 Atas Dasar Harga Berlaku Menurut Lapangan Usaha (Persen) Kabupaten Sragen”

Badan Pusat Statistik Kabupaten Sragen. Januari 2019. https://sragenkab.bps.go.id/subject/52/produk-domestik-regional-bruto--lapanganusaha-.html\#subjekViewTab5. "Laju Pertumbuhan Ekonomi Kabupaten Sragen Tahun 2011-2016"

Badan Pusat Statistik Kabupaten Sragen. 2018. Produk Domestik Regional Bruto Kabupaten Sragen menurut Lapangan Usaha 2013-2017. Badan Pusat Statistik Kabupaten Sragen.

Badan Pusat Statistik Provinsi Jawa Tengah. Januari 2019. https://jateng.bps.go.id/subject/52/produk-domestik-regional-bruto--lapanganusaha-.html\#subjekViewTab5. "Distribusi Persentase PDRB Seri 2010 Atas Dasar Harga Berlaku Menurut Lapangan Usaha (Persen) Provinsi Jawa Tengah" 
Badan Pusat Statistik Provinsi Jawa Tengah. Januari 2019. https://jateng.bps.go.id/subject/52/produk-domestik-regional-bruto--lapanganusaha-.html\#subjekViewTab5. "Laju Pertumbuhan Ekonomi Provinsi Jawa Tengah Tahun 2011-2017"

Mahmudi. 2009. Manajemen Keuangan Daerah. Jakarta: Erlangga.

Nasution, Yohan dan Suparta, I Made. 2018. Strategi Peningkatan Pertumbuhan Ekonomi melalui Analisis Sektor Basis di Kota Batu Periode 2010-2014. JEB 17 Volume 3 Nomor 1. 543-554.

Nuraini, Rica Ayu dan Setiartiti, Lilies. 2017. Strategi Pengembangan Kota Magelang sebagai Kawasan Andalan di Provinsi Jawa Tengah. Jurnal Ekonomi \& Studi Pembangunan Volume 18 Nomor 2. 173-182.

Nurhasanah, Aan dkk. 2018. Analisis Kelayakan dan Strategi Pengembangan Wilayah dalam Wacana Pembentukan Daerah Otonom Baru Bogor Timur. TATA LOKA Volume 20 Nomor 3. 282-294.

Peraturan Bupati Sragen Nomor 120 Tahun 2016 tentang Penetapan Indikator Kinerja Utama Pemerintah Daerah Kabupaten Sragen dan Indikator Kinerja Utama Organisasi Perangkat Daerah Kabupaten Sragen Tahun 2016-20121

Pratiwi, Niken; Santosa, Dwi Budi dan Ashar, Khusnul. 2018. Analisis Implementasi Pembangunan Berkelanjutan di Jawa Timur. JIEP-Vol. 18 No. 1.

Putra, Putu Indra Perdana dan Yadnya, I Putu. 2018. Analisis Sektor Unggulan Perekonomian di Kabupaten/Kota Denpasar, Badung, Gianyar dan Tabanan. EJurnal Manajemen Unud Vol 7 No. 10. 5657-5685.

Sukirno, Sadono. 2010. Pengantar Teori Makro Ekonomi. Jakarta: PT Raja Grafindo 